Edunomika - Vol. 02, No. 02 (Agustus 2018)

\title{
PENGARUH MANAJEMEN PENGETAHUAN TERHADAP KUALITAS PENDIDIKAN DI SMK KASATRIAN SOLO SUKOHARJO
}

\author{
Imam Taqorub, Supawi Pawenang, Solichuul Hadi AB. \\ Fakultas Ekonomi, Universitas Islam Batik Surakarta \\ imamtaqorub1@yahoo.co.id
}

\begin{abstract}
The purpose of this study was to: (1) To describe the effect of Knowledge Management (2) To describe the influence of Teacher professionalism (3) To describe the effect of Recruitment process (4) To describe the influence of the Mastery of Information and Communication Technology on Quality Education In SMK Kasatrian Solo Sukoharjo. The research was in SMK Kasatrian Solo Sukoharjo. The population in this research were 821 teacher and students. Samples taken as many as 206. In this study, the data used are: (1)The primary data include: identity and responder. (2)Secondary data in the form of literature studies, journals, literature relating to the cases, and documentation information, and the Internet. The technique of collecting data by questionnaire, interview and documentation. Testing instrument with validity and reliability. Data analysis techniques in this study using a test classic assumptions and hypothesis testing. The classical assumption, among others, with the test data normality, autocorrelation, multicollinearity and heteroscedasticity. Hypothesis testing Regression test, $t$ test, $F$ test, and test Coefficient of Determination.The results of this study are: Teacher professionalism, Recruitment process and the Mastery of Information and Communication Technology can be implemented and need to be improved considering that positive and significant impact on quality education In SMK Kasatrian Solo Sukoharjo.
\end{abstract}

Keywords: Knowledge Management, Teacher professionalism, Recruitment process, Mastery of Information and Communication Technology, quality education

\section{PENDAHULUAN}

Hasil penelitian empiris menunjukkan di dunia internasional bahwa kualitas pendidikan Indonesia berdasarkan Indeks Pembangunan Manusia (IPM) dengan angka 0,629 tahun 2013 dalam laporan Program Pembangunan PBB, Indonesia berada pada posisi 121 dari 185 negara. Hal ini Indonesia tertinggal dari dua negara tetangga ASEAN yaitu Singapura peringkat 18 dan Malaysia peringkat 64, sedangkan IPM di kawasan Asia Pasifik adalah 0,683 (USAID, 2013). Kualitas pendidikan dapat dinyatakan sebagai karakteristik jasa di bidang pendidikan. Sesuai dengan kriteria tertentu dalam memenuhi kepuasan pengguna (user) pendidikan, seperti siswa, wali murid, perusahaan serta pihak-pihak berkepentingan lainnya. Untuk menjaga kualitas proses tersebut, diperlukan adanya pengawasan atau kontrol kualitas yang mengawasi pelaksanaan proses dan segala komponen yang mendukung. Sekolah adalah sebuah institusi yang dipilih oleh masyarakat, dalam proses kerjanya selalu berhadapan dengan ketidakpastian. Hal ini bahwa kondisi input dan lingkungan tidak pernah sama dengan lingkungan lain maka proses kerja di sekolah secara teknis tidak dapat dipastikan. Demikian juga lingkungan keluarga dan pergaulan peserta didik tidak dapat dipisahkan di dalam proses pendidikan di sekolah. (Depdiknas, 2009).

Dengan adanya peran sumber daya manusia yang profesional, proses penerimaan guru baru dan penguasan teknologi dan informasi merupakan bentuk pelaksanaan manajemen pengetahuan di sekolah (Dalkir, 2011). Manajemen pengetahuan dalam menyatukan pemahaman yang luas sebgai dampak dari teknologi informasi yang semakin maju dapat di terapkan oleh lembaga Pendidikan hal ini sekolah (Petrides dan Nguyen, 2006). Faktor-faktor yang mempengaruhi manajemen pengetahuan dalam dunia pendidikan adalah: 1) People, yaitu guru yang profesional, yang mampu memberikan fasilitas pembelajaran kepada siswa agar berkembang secara bertahap; 2) Processes, yaitu proses rekruitmen sebagai proses untuk menjaring karyawan, pendidik dan tenaga kependidikan; dan 3) 
Technologies, pemanfaatan dan penguasaan Teknologi Informasi dan Komunkasi atau TIK dalam proses pembelajaran.

Profesionalitas guru berkaitan dengan pekerjaan seseorang merupakan arah dan tujuan untuk meningkatkan kualitas suatu keahlian dan kewenangan dalam bidang pendidikan dan pengajaran dapat menjadi mata pencaharian. Sedangkan guru yang profesional adalah guru dengan keahlian dan memiliki kompetensi dipersyaratkan dapat melaksanakan tugas pendidikan dan pengajaran. Jadi guru profesional adalah pendidik dapat dan mampu melaksanakan fungsi dan tugasnya sebagai pendidik di bidang pendidikan dan pengajaran dengan kemampuan dan keahlian maksimal.

Menurut Kamal (2015), proses rekruitmen adalah pelaksanaan untuk mendapatkan sejumlah sumber daya manusia atau guru yang berkualitas untuk menduduki suatu pekerjaan dan jabatan dalam suatu sekolah. Aziz et al., (2017) menjabarkan beberapa poin penting yang telah mengidentifikasi rekruitmen internal karyawan referensi, perencanaan suksesi, wawancara, tes kepribadian, perekrutan koran, lembaga pencari profesional, dan biodata sebagai praktek kepegawaian tingkat senior dominan.

Teknologi Informasi dan komunikasi dipandang sebagai proses dan struktur tertentu Antari et al., (2016), ini berarti bahwa teknologi informasi dan komunikasi seharusnya di jadikan bagian yang menyatu dalam sistem pendidikan. Perubahan peran guru di dalam satuan pendidikan sebagai akibat dari masuknya teknologi informasi yang menyatu di dalam satuan pendidikan. Sehingga guru lebih berperan menjadi motifator, perancang proses dan fasilitator bagi proses belajar siswa tidak lagi menjadi satusatunya sumber belajar.

Implementasi knowledge management diharapkan dapat meningkatkan mutu pendidikan di sekolah. Dalam konteks implementasi knowledge management sumber daya manusia (people) bukan sistem, tetapi organisasi dapat memberdayakan sumber daya manusia untuk sharing dan manage knowledge sebagaimana dikemukakan Petrides dan Nodine (2003), bahwa people not systems, manage knowledge. But organizations can promote policies and practices that help people share and manage knowledge. Melalui praktik dan mempromosikan kebijakan manage knowledge organisasi dapat memanfaatkan sumber daya untuk mencapai produktivitas organisasi di berbagai bidang sehingga mampu bersaing dengan menggunakan aset intelektual yang juga sebagai human capital. Demikian pula hasil penelitian Christin (2006) menujukkan bahwa keberhasilan implementasi Knowledge Management System (KMS) dapat meningkatkan produktivitas organisasi diberbagai bidang.

Dalam era informasi penting untuk disadari bahwa aliran knowledge ke dalam dan keluar organisasi berlangsung sangat cepat. Dengan pemanfaatan teknologi informasi, revolusi penyebaran dan pemanfaatan pengetahuan bukan merupakan hal yang aneh. Banyak organisasi dewasa ini mengadopsi dan mengimplementasikan Knowledge Management (Manajemen Pengetahuan) sebagai sarana dalam menunjang proses-proses yang terkait dengan pemberdayaan pengetahuan yang mereka miliki.

Manajemen Pengetahuan sebagai upaya untuk melakukan sesuatu yang berguna terhadap pengetahuan untuk mencapai tujuan organisasi melalui manusia sebagai sumber daya (Nejad dan Abbaszadeh, 2010). Sumber daya manusia sebagai ujung tombak dari menejemen pengetahuan untuk meningkatkan kinerja dan mutu pendidikan sehingga lembaga pendidikan dimana tempat bekerja dapat bersaing dengan lembaga lain dan meningkatnya kepercayaan masyarakat karena manajemen pengetahuan menurut Davenport et al., (2000) tersebut, terdiri atas proses untuk menjaring, mendistribusikan dan menggunakan pengetahuan secara efektif.

Lembaga pendidikan dalam usahanya untuk melayani pelanggannya memiliki banyak sekali permasalahan yang muncul ketika menjalankan perannya didalam masyarakat, mulai dari guru atau tenaga pendidik, proses pembalajaran dan teknologi yang digunakan (Ceha at al., 2016). Dari 
berbagai permasalahan yang ada diadakan pemetaan permasalahan, kemudian melakukan proses pengetahuan didalam lembaga pendidikan tersebut, dari kenyataan yang ada saat ini lembaga pendidikan berada didalam lingkungan global, sehingga termotivasi untuk bersaing dengan berusaha menemukan penemuan-penemuan baru atau inovasi dengan kemampuan yang dimiliki oleh lembaga pendidikan tersebut. Untuk mengimplementasikan pengetahuan manajemen yang efektif lembaga pendidikan di tingkat pemenangan kompetensi. Proses pengetahuan akan menghasilkan bentuk permasalahan yang tepat, penggunaan model organisasi, proses pemecahan masalah yang dilaksanakan dengan melakukan pengamatan dan penelitian sesuai dengan pemetaan permasalahan yang tepat.

Berdasarkan hasil pengamatan peneliti, permasalahan yang ada di SMK Kasatrian Solo Sukoharjo yang berkaitan dengan mutu/kualitas pendidikan antara lain: rendahnya profesionalitas guru, kurang tepatnya sistem rekruitmen guru dan masih rendahnya penguasaan Teknologi Informasi dan Komunikasi. Rendahnya profesionalitas guru dibuktikan kurang lebih $40 \%$ dari jumlah guru yang kesulitan dalam menyusun perangkat pembelajaran yang sesuai dengan silabus. Sebagian besar guru menggunakan Rencana Pelaksanaan Pembelajaran (RPP) selama bertahun-tahun tanpa adanya pembaruan dan inovasi. Guru juga masih kurang tertib dalam pelaksanaan administrasi kelas, sebagian besar guru hanya mengajar saja tanpa melaksanakan administrasi kelas. Sistem rekruitmen guru di SMK Kasatrian Solo Sukoharjo selama ini belum memiliki standar operasional prosedur (SOP) yang baku, proses rekruitmen guru masih menggunakan cara tradisional yaitu berdasarkan kedekatan atau rekomendasi dari orang yang ada di SMK Kasatrian Solo Sukoharjo. Penggunaan dan penguasaan Teknologi komunikasi dan Informasi dalam kegiatan pembelajaran dan administrasi di SMK Kasatrian Solo Sukoharjo masih rendah. Dalam pembelajaran sebagian guru masih menggunakan metode konvensional dan belum memanfaatkan TIK dengan optimal. Demikian juga dengan kegiatan administrasi sekolah, masih belum menggunakan TIK secara terintegrasi dan menyeluruh. Hasil nilai ujian nasional dari tahun 2015-2017 selalu turun.

Tabel 1 Rerata Nilai Ujian Nasional Smk Kasatrian Solo Sukoharjo

\begin{tabular}{lccc}
\hline \multicolumn{1}{c}{ Mata Pelajaran } & $\mathbf{2 0 1 7}$ & $\mathbf{2 0 1 6}$ & $\mathbf{2 0 1 5}$ \\
\hline Bahasa Inggris & 34.15 & 43.55 & 46.83 \\
Bahasa Indonesia & 63.05 & 65.60 & 62.78 \\
Kompetensi Kejuruan & 70.04 & 67.98 & 81.15 \\
Matematika & 31.14 & 29.66 & 34.08 \\
Rerata & $\mathbf{4 9 . 6 0}$ & $\mathbf{5 1 . 7 0}$ & $\mathbf{5 6 . 2 1}$ \\
\hline
\end{tabular}

Sumber : https://puspendik.kemdikbud.go.id/hasil-un

Ketiga permasalahan di SMK Kasatrian Solo Sukoharjo yang berkaitan dengan mutu/kualitas pendidikan diatas merupakan aspek-aspek dalam manajemen pengetahuan. Dalam meningkatkan mutu pendidikan di sekolah dalam jangka waktu tertenut pada tahap perencanan, seorang guru merumuskan silabus. Dalam perumusan silabus memperhatikan kondisi siswa, terutama hal yang menyangkut dalam ranah kognitif, efektif, psikomotorik, metode yang tepat untuk pembelajaran, serta target yang harus diselesaikan (Santoso, 2007). Seorang Guru dituntut menggunakan teknologi informasi dan komunikasi sehingga tingkat pemahaman siswa meningkat. Sehingga dapat menghasilkan keuntungan bagi institusi pendidikan (Sopandi, 2016).

Penelitian terdahulu oleh Ferdinandus et al., (2015) penelitian tersebut berkesimpulan, transformasi pengetahuan explicit to tacit sudah dilakukan oleh para guru, dengan baik, belum maksimalnya di lakukan sosialisasi,adanya sikap demokratis oleh kepala sekolah SMA Negeri 1 Pulau Aru dan sikap paternalis oleh kepala sekolah SMK Yos Sudarso Dobo, sudah mengaplikasikan pengetahuan dari luar dan kedua sekolah sudah melaksanakan proses knowledge capture dengan baik. 
Persamaan penelitian Ferdinandus et al.,(2015) dengan penelitian ini adalah meneliti tentang manajemen pengetahuan di jenjang Sekolah Menengah. Perbedaanya, penelitian ini fokus pada pengaruh manajemen pendidikan terhadap mutu pendidikan di SMK.

Penelitian oleh Sopandi (2016) Penelitian ini berkesimpulan bahwa kebijakan teknis mendukung untuk manajemen pengetahuan di ITB digambarkan dalam visi, misi dan tujuan dari ITB. Penerapan manajemen pengetahuan di ITB dilihat dari aspek orang dilakukan melalui pengembangan kompetensi sumber daya manusia, proses manajemen pengetahuan sejalan dengan meningkatnya fokus pada "Tridharma Perguruan Tinggi". Persamaan penelitian Omar Dani Sopandi dengan penelitian ini adalah sama-sama meneliti tentang manajemen pengetahuan di institusi pendidikan. Perbedaanya, penelitian ini fokus pada pengaruh manajemen pendidikan terhadap mutu pendidikan di SMK.

\section{METODE PENELITIAN}

Penelitian ini dilaksanakan di SMK Kasatrian Solo Sukoharjo. dengan pertimbangan bahwa sekolah tersebut pada saat ini memerlukan strategi dalam meningkatkan kualitas pendidikan berkaitan dengan ketatnya persaingan dengan sekolah lain yang sejenis. Pemilihan lokasi penelitian melalui observasi untuk mengetahui gambaran umum sekolah.

Tabel 2. Jumlah Sampel Kasatrian Solo Sukoharjo

\begin{tabular}{cccc}
\hline No. & Deskripsi & $\begin{array}{c}\text { Jumlah } \\
\text { Populasi }(\mathrm{N})\end{array}$ & $\begin{array}{c}\text { Jumlah } \\
\text { Sampel }\left(\mathrm{n}_{\mathrm{i}}\right)\end{array}$ \\
\hline 1 & Guru & 65 & 32 \\
2 & Siswa kelas XII & 277 & 58 \\
3 & Siswa kelas XI & 242 & 58 \\
4 & Siswa kelas X & 237 & 58 \\
& Jumlah & 821 & 206 \\
\hline
\end{tabular}

Teknik pengambilan sampel dalam penelitian ini menggunakan teknik proportional random sampling, di mana tiap kelas diambil secara proporsional yang mewakili tiap-tiap kelas. Dari populasi di atas akan diteliti dari beberapa variabel yaitu

1. Profesionalitas guru $\left(\mathrm{X}_{1}\right)$ adalah seperangkat kemampuan dan kompetensi atau kecakapan harus dimiliki oleh guru. Sehingga dapat melaksanakan tugas pembelajaran dengan berhasil. Indikator yang diukur meliputi: Mampu menguasai bahan pembelajaran yang di tugaskan. Dapat mengelola program belajar mengajar. Mampu mengelola kelas. Dapat menggunakan media atau sumber belajar. Dapat mengelola interaksi belajar mengajar. Dapat membuat penilaian prestasi belajar siswa dan Mampu menafsirkan hasil penelitian.

2. Rekruitmen Guru $\left(X_{2}\right)$ adalah pelaksanaan untuk mendapatkan sejumlah sumber daya manusia (guru) yang berkualitas untuk menduduki suatu pekerjaan atau jabatan di sekolah. Indikator yang digunakan meliputi: Dasar sumber penarikan guru, Sumber guru, dan Metode Penarikan guru.

3. Teknologi Komunikasi dan Informasi $\left(\mathrm{X}_{3}\right)$ merupakan sebuah komponen alat bantu dalam memperoleh pengetahuan antara guru dengan siswa. Indikator yang digunakan meliputi: komponen atau perangkat keras, komponen atau Perangkat lunak, dan Kemampuan manusia dalam menggunakan komponen atau perangkat tersebut.

4. Mutu pendidikan (Y) adalah pelaksanaan pendidikan dengan harapan tinggi untuk dicapai dari pengembangan bakat-bakat para pelanggan pendidikan melalui proses pendidikan. Indikator yang diukur adalah: Kecukupan sumber-sumber pendidikan; Mutu proses belajar mengajar, Mutu keluaran dalam bentuk pengetahuan, sikap keterampilan. 
Metode penelitian dengan menggunakan :

a. Uji Validitas yaiut nilai yang diperoleh menunjukkan sejauh mana perbedaan instrumen pengukuran dan kemajemukan pada objek penelitian Kriteria keputusan kesahihan dinyatakan apabila nilai $r$ yang diperoleh dari hasil perhitungan $\left(r_{x y}\right)$ lebih besar dari pada nilai $r_{\text {tabel }}\left(r_{t}\right)$ dengan taraf signifikansi $5 \%$ atau nilai probabilitas value kurang dari 0,05 , maka butir-butir pertanyaan adalah valid atau sahih (Arikunto, 2006).

b. Uji normalitas dan heteroskedastisitas digunakan untuk mengetahui apakah variabel yang dianalisis memenuhi kriteria distribusi normal (Gujarati, 2005). Kriteria pengujian jika nilai probabilitas value $>0,05$ maka lolos uji normalitas.

c. Uji Multikolinieritas dengan Kriteria pengujian jika nilai tolerance variable independent lebih dari 0,01 dan nilai VIF kurang dari 10 berarti tidak terjadi multikolinieritas (Kuncoro, 2001).

\section{HASIL DAN PEMBAHASAN PENELITIAN}

\section{Karakteristik Responden.}

Populasi penelitian adalah guru berjumlah 65 orang dan siswa SMK Kasatria Solo Sukoharjo berjumlah 756 siswa. Guru mengajar mata pelajaran normatif sebanyak 8, mengajar mata pelajaran adaptif sebanyak 20 dan mengajar mata pelajaran kejuruan sebanyak 37 guru. Jumlah siswa pria sebanyak 490(65\%), siswa perempuan 266 (35\%). (data administrasi sekolah smk kasatrian solo sukoharjo, 2017).

Hasil Karakteristik responden penelitian diambil guru 32 orang dan siswa 174. Usia siswa 16 tahun sejumlah 66 (38\%), usia 17 tahun sejumlah 72 (41\%) dan usia 18 tahun sebanyak 36 siswa (21\%). Bersadarkan jenis kelamin 126 orang laki-laki (61\%) dan perempuan sebanyak 80 orang (39\%). Jumlah siswa jurusan teknik kendaraan ringan 38 (22\%), Teknik sepeda motor 39 (22\%), Pemasaran 12 (7\%), Akomodasi Perhotelan (24\%), Jasa Boga 20 (11\%) dan Teknik kendaraan ringan 24 (14\%).Semua kuesioner telah diisi dengan lengkap dan digunakan sebagai dasar dalam penelitain untuk analisis data.

\section{Pengujian Hipotesis.}

1. Analisis Regresis Berganda

Penelitian ini menggunakan uji regresi berganda dengan variabel bebas $(\mathrm{X})$ yaitu Profesoinalitas guru $\left(\mathrm{X}_{1}\right)$, proses rekruitmen $\left(\mathrm{X}_{2}\right)$ dan Teknologi Informasi dan Komunikasi $\left(\mathrm{X}_{2}\right)$ terhadap variabel terikat (Y) kualitas pendidikan. Angka yang di peroleh menggunakan SPSS for Windows release 20 padaPerhitungan koefisien regresi dapat dilihat pada tabel berikut:

Tabel 3 Analisis Regresi Berganda

\begin{tabular}{|c|c|c|c|c|c|c|}
\hline & \multirow[b]{2}{*}{ Model } & \multicolumn{2}{|c|}{$\begin{array}{l}\text { Unstandardized } \\
\text { Coefficients }\end{array}$} & \multirow{2}{*}{$\begin{array}{c}\text { Standardized } \\
\text { Coefficients } \\
\text { Beta }\end{array}$} & \multirow[b]{2}{*}{$t$} & \multirow[b]{2}{*}{ Sig. } \\
\hline & & B & Std. Error & & & \\
\hline \multirow[t]{4}{*}{1} & (Constant) & .803 & .395 & & 2.031 & .044 \\
\hline & $P G$ & .142 & .018 & .137 & 7.838 & .000 \\
\hline & PR & .972 & .014 & .939 & 70.332 & .000 \\
\hline & TIK & .181 & .020 & .181 & 8.976 & .000 \\
\hline
\end{tabular}

Sumber: Lampiran 5

Dari persamaan regresi berganda di atas hasil analisis yang terdapat dalam perhitungan yaitu:

$$
\mathrm{Y}=0,803+0,142 \mathrm{X}_{1}+0,972 \mathrm{X}_{2}+0,181 \mathrm{X}_{3}
$$

Makna dari persamaan regresi berganda tersebut:

Jika variabel Profesoinalitas guru, proses rekruitmen, Teknologi Informasi dan Komunikasi diasumsikan 0 , maka kualitas pendidikan 0,803. Jika faktor lain yang mempengaruhi dianggap 
konstan. Koefisien regresi 0,181 menyatakan bahwa setiap peningkatan 1 poin Teknologi Informasi dan Komunikasi sementara Profesoinalitas guru dan proses rekruitmen dianggap tetap. Maka akan meningkatkan prestasi belajar siswa 0,181 , dalam hal ini faktor lain yang mempengaruhi dianggap tetap.

a. Pengaruh Profesionalitas Guru terhadap kualitas Pendidikan

Koefisien regresi 0,142 menyatakan bahwa setiap peningkatan 1 poin Profesoinalitas guru sementara proses rekruitmen, Teknologi Informasi dan Komunikasi dianggap tetap, maka akan meningkatkan kualitas pendidikan sekolah sebesar 0,142 , dalam hal ini faktor lain yang mempengaruhi dianggap konstan. Dari penelitian ini membuktikan bahwa Profesionalitas guru berpengaruh terhadap kualitas pendidikan. Dengan adanya peningkatan profesionalitas guru maka kualitas pendidikan akan mengalami peningkatan. Penelitian ini mendukung dari penelitian sebelumnya (Salo, 2011). Institusi pendidikan di Indonesia harus mengelola pengetahuan sebagai jantung pendidikan secara berkelanjutan dan menerapkan konsep manajemen pengetahuan salah satunya adalah profesionalisme guru dari perspektif pendidikan dan mengeksplorasi strategi dalam mempertahankan manajemen pengetahuan di bidang pendidikan.

Dapat disimpulkan berdasarkan penjelasan di atas bahwa profesional guru di SMK Kasatrian Solo Sukoharjo yang memiliki kemampuan dan keahlian khusus dalam bidangnya masing-masing serta memiliki berpengalaman dalam mengajar sehingga guru dapat melaksanakan fungsi dan tugasnya sebagai guru dengan maksimal serta mempunyai kompetensi sesuai dengan rambu guru profesional dan profesi tersebut menjadi sumber mata pencaharian perlu ditingkatkan demi tujuan bersama antara sekolah dan guru. Semakin profesional guru dalam menjalan tugasnya maka kualitas pendidikan di semakin meningkat.

b. Pengaruh proses rekruitmen terhadap kualitas pendidikan.

Koefisien regresi 0,972 menyatakan bahwa setiap peningkatan 1 poin proses rekruitmen sementara Profesoinalitas guru dan Teknologi Informasi dan Komunikasi dianggap tetap, maka akan meningkatkan kualitas pendidikan sekolah sebesar 0,972 , dalam hal ini faktor lain yang mempengaruhi dianggap konstan. Dalam penelitian ini membuktikan bahwa proses rekruitmen guru mempunyai pengaruh terhadap mutu pendidikan. Menyatakan semakin baik proses rekruitmen calon guru maka semakin baik mutu pendidikan dalam melayani proses pembelajaran yang berkualitas. Hasil ini mendukung penelitian terdahulu. Ferdinandus et al., (2015). Penelitian ini menggambarkan bahwa proses rekruitmen bertujuan mendapatkan guru melakukan transformasi pengetahuan dengan baik ketika melakukan persiapan pembelajaran sehingga dalam proses pembelajaran menghasilkan kualitas yang baik dan dapat dirasakan oleh para siswa dengan demikian dapat meningkatkan kualitas pendidikan.

Proses rekruitmen adalah suatu proses di dalam manajemen suatu lembaga pendidikan untuk mendapatkan karyawan, guru, pegawai terbaik untuk menjalankan fungsi dan tugas pokoknya sesuai dengan peraturan dan kebijakan yang berlaku di SMK Kasatrian solo Sukoharjo. Hasil dari proses rekutmen adalah mendapatkan sumber daya manusia terbaik yang mampu melakukan fungsi dan tugas pokoknya sehingga dapat meningkatkan kualitas pendidikan di SMK Kasatrian Solo Sukoharjo.

c. Pengaruh penguasaan teknologi informasi dan komunikasi terhadap mutu pendidikan.

Koefisien regresi 0,181 menyatakan bahwa setiap peningkatan 1 poin Teknologi Informasi dan Komunikasi sementara Profesoinalitas guru dan proses rekruitmen dianggap tetap. Maka akan meningkatkan prestasi belajar siswa 0,181 , dalam hal ini faktor lain yang mempengaruhi dianggap tetap.Dengan adanya penelitian ini membuktikan bahwa penguasaan teknologi informasi dan komunikasi berpengaruh terhadap mutu pendidikan. Apabila guru mempunyai penguasaan yang bagus dalam bidang teknologi informasi dan komunikasi maka mutu atau kualitas pendidikan semakin baik. Dari penelitian ini mendukung penelitian terdahulu (Qwaider, 2011). Dalam penelitian ini peningkatan penangkapan transformasi pengetauan dapat ditingkatkan dengan adanya teknologi informasi dan komunikasi. Sehingga proses pembelajaran merupakan transfer ilmu pengatahuan dari guru kepada siswa dapat ditingkatkan dengan adanya teknologi informasi dan komunikasi. Maka guru yang memiliki penguasaan teknologi informasi 
dan komunikasi denga baik dan benar dapat meningkatkan kualitas pendidikan di SMK Kasatrian Solo Sukoharjo.

Penguasaan teknologi informasi dan komunikasi dapat diartikan sebagai sumber daya manusia mampu menggunakan semua teknologi atau alat yang membantu dalam upaya untuk pengambilan, pengumpulan, pengolahan, penyimpanan, penyebaran, dan penyajian informasi kepada siswa atau pihak lain. Teknologi informasi dan komunikasi seharusnya di jadikan bagian integral sistem pendidikan. Sebagai bagian integral, masuknya komponen teknologi ini akan mempengeruhi komponen lain diantaranya perubahan peranan guru dalam satuan pendidikan sekolah. Peranan guru dalam ini tidak lagi menjadi satu satunya sumber belajar, melainkan lebih berperan sebagai perancang proses pembelajaran, fasilitator dan motifator bagi proses belajar siswa, sehingga penguasaan dan kemampuan sumber daya manusia dalam menjalankan teknologi informasi dan komunikasi yang baik dan benar akan meningkatkan kualitas pendidikan di SMK Kasatrian solo sukoharjo.

\section{Koefisien Determinasi}

Nilai adjusted $\mathrm{R}^{2}$ sebesar 0,983 dari tabel diatas menunjukkan bahwa ada kontribusi sebesar 98,3\% dalam kaitan ini Profesoinalitas guru, proses rekruitmen, Teknologi Informasi dan Komunikasi terhadap kualitas pendidikan secara bersamaan. Sisanya 1,7\% dijelaskan oleh sebabsebab hal lain yang diluar variabel penelitiaan.

\section{Uji F}

Berdasarkan uji $\mathrm{F}$, menghasilkan $\mathrm{F}_{\text {hitung }}$ sebesar 38,96. Level signifikansi yang digunakan yaitu 0,05 jadi tingkat signifikansi 0,000 jauh lebih kecil. (Ho) ditolak berdasarkan hasil tersebut , artinya ada pengaruh secara signifikan secara simultan antara profesoinalitas guru, proses rekruitmen, teknologi informasi dan komunikasi terhadap kualitas pendidikan sekolah SMK Kasatrian solo Sukoharjo.

4. Uji t

a. Pengaruh Profesoinalitas guru terhadap kualitas pendidikan

Diperoleh $\mathrm{t}_{\text {Hitung }}$ sebesar 7.838 karena $\mathrm{t}$ dinyatakan dengan tanda positif dari hasil perhitungan uji $t$ untuk variabel Profesoinalitas, maka semakin tinggi profesoinalitas guru maka semakin tinggi pula kualitas pendidikan SMK Kasatrain Solo Sukoharjo. $\mathrm{H}_{0}$ ditolak dengan angka signifikan sebesar $0,000<0.05$ maka, $\mathrm{H}_{2}$ diterima. Artinya Profesoinalitas guru $\left(\mathrm{X}_{1}\right)$ berpengaruh yang signifikan terhadap kualitas pendidikan SMK Kasatria Solo Sukoharjo (Y) secara parsial.

b. Pengaruh proses rekruitmen terhadap kualitas pendidikan sekolah

Diperoleh $\mathrm{t}_{\text {Hitung }}$ sebesar 70.332 karena $t$ dinyatakan dengan tanda positif maka berdasarkan hasil perhitungan uji t untuk variabel proses rekruitmen. Semakin tinggi proses rekruitmen maka semakin tinggi pula kualitas pendidikan SMK Kasatrian Solo Sukoharjo. H0 ditolak, $\mathrm{H}_{3}$ diterima dengan angka signifikan sebesar $0,000<0.05$. Hal ini berarti ada pengaruh yang signifikan antara proses rekruitmen $\left(\mathrm{X}_{2}\right)$ terhadap kualitas pendidikan SMK Kasatrian Solo Sukoharjo (Y) secara parsial.

c. Pengaruh Teknologi Informasi dan Komunikasi terhadap kualitas pendidikan sekolah

Diperoleh $\mathrm{t}_{\text {Hitung }}$ sebesar 8.976 karena t dinyatakan dengan tanda positif. Berdasarkan hasil perhitungan uji $t$ untuk variabel Teknologi Informasi dan Komunikasi. Semakin tinggi Teknologi Informasi dan Komunikasi maka semakin tinggi pula kualitas pendidikan SMK Kasatrain Solo Sukoharjo. $\mathrm{H}_{0}$ ditolak, $\mathrm{H}_{3}$ diterima dengan angka signifikan sebesar $0,000<0.05$. Berarti ada pengaruh yang signifikan antara pengaruh Teknologi Informasi dan Komunikasi $\left(\mathrm{X}_{3}\right)$ terhadap kualitas pendidikan SMK Kasatrian Solo Sukoharjo (Y) secara parsial.

\section{KESIMPULAN}

Profesionalitas guru mempengaruhi kualitas pendidikan SMK Kasatrain Solo Sukoharjo. Pelaksanaan untuk meningkatkan kualitas pendidikan melalui profesionalitas guru dengan meningkatkan kemampuan menguasai bahan pembelajaran yang di tugaskan, meningkatkan pengolahan 
program belajar dan mengajar, meningkatka kemampuan mengelola kelas, meningkatkan penggunaan alat dan sumber belajar, meningkatkan pengelolaan interaksi belajar mengajar, meningkatkan pembuatan penilaian prestasi belajar siswa dan meningkatkan kemampuan menafsirkan hasil penelitian tindakan kelas.

Proses rekruitmen berpengaruh terhadap kualitas pendidikan SMK Kasatrian Solo Sukoharjo.Pelaksanaan untuk meningkatkan kualitas pendidikan melalui proses rekrtumen dengan peningkatan prosedur proses rekruitmen dengan menjabarkan beberapa poin penting yang telah mengidentifikasi rekruitmen internal karyawan referensi, perencanaan suksesi, wawancara, tes kepribadian, perekrutan koran, lembaga pencari profesional, dan biodata sebagai praktek kepegawaian tingkat senior dominan, sehingga akan mendapatkan sumber daya manusia unggul dalam menjalankan tugas dan fungsinya

Penguasaan teknologi informasi dan komunikasi berpengaruh terhadap kualitas pendidikan SMK Kasatrian Solo Sukoharjo. Usaha yang dilakukan untuk meningkatkan kualitas pendidikan melalui penguasaan teknologi informasi dan komunikasi dengan penambahan sarana dan prasarana perangkat keras seperti komputer, lap top, LCD, sound sistem dan lampu penerangan yang cukup,menambah aplikasi untuk proses pembelajaran edmodo, office 365 dan perangkat lunak lainnya dan peningkatan keterampilan manusia dalam menggunakan aplikasi pembelajaran yang baik dan benar.

\section{DAFTAR PUSTAKA}

Antari, D, M, Agustini, K, dan Divayana, H. 2016. Studi Komparatif Model Pembelajaran Talking Stick dan Snowball Throwing Terhadap Hasil Belajar Teknologi Informasi dan Komunikasi (TIK) Siswa Kelas XI SMK Negeri Serirt Tahun Ajaran 2015/2016.Jurnal Pendidikan Teknologi dan Kejuruan Vol.13,N0.2, hal.129

Arikunto, S. 2006. Prosedur Penelitian Suatu Pendekatan Praktik. Jakarta: Rineka Cipta

Aziz, T, Maarif, S, Sukmawati, A. 2017. Pengaruh Rekruitmen dan Seleksi Terhadap Kinerja. Jurnal Aplikasi Bisnis dan Manajemen,Vol.3 No.2, hal. 248

Ceha, R, Prasetyningsih, E, Bahctiar, I, dan Nana, A. 2016. Peningkatan Kemampuan Guru Dalam Pemanfaatan Teknoligi dan Informasi PadaKegiatan Pembelajaran, Jurnal Penelitian dan Pengabdian kepada Masyarakat, Vol.4 No.1, hal. 131-138

Christin, 2006. Peran Budaya Organisasi Dalam Mendukung Keberhasilan Implementasi Knowledge Management Systems. BINA EKONOMI VoI. 10, No. 1, Januari2006: hal. 1-120.

Prawati. 2017. Data Adminstrasi Sekolah SMK Kasatrian Solo Sukoharjo.

Dalkir, K. 2005. Knowledge Management In Theory and Practice. USA Linacre House, Jordan Hill, Oxford OX2 8DP, UK Elsevier Butterworth-Heinemann 30 Corporate Drive, Suite 400, Burlington, MA 01803.

Dalkir, K. 2011. Knowledge Management in Theory and Practice. Elsevier, Butterworth-Heinemann USA. Burlington, United State of America.

Davenport, Thomas, H, dan Laurence, P. 2000. Working Knowledge: How Organization Managemen What They Know. Harvard: Harvard busines Press, hal. 240.

Depdiknas, 2009. Permendiknas No. 58/2009 tentang standar Tingkat. Pencapaian Perkembangan. Jakarta: Depdikbud. 
Imam Taqorub, dkk / Edunomika Vol. 02 No. 02 (Agustus, 2018)

Ferdinandus, E, Imron, A, dan Supriyanto, A. 2015. Model Knowledge Management Dalam Organisasi Pendidikan, Jurnal Pendidikan Humaniora, Vol. 3 No. 2, hal. 106-115

Gujarati. 2005. SPSS Versi 16 Mengolah Data Statistik Secara Profesional. Jakarta: Gramedia Pustaka Utama

Kemendikbud. 2017. Rekap Hasil Ujian Nasional (UN) Tingkat Sekolah Diakses tanggal 10 Oktober 2017. Tersedia di https://www.puspendik.kemdikbud.go.id/hasil-un/

Kamal, F.2015. Tijauan Proses Rekruitmen dan Selekdi Calon Karyawan (Studi Kasus pada PT Berkah Makmur Jakarta). ISSN: 2355-0295.Vol III .No.2, hal. 26-29

Kuncoro, M. 2001. Metode Kuantitatif: Teori dan Aplikasi untuk Bisnis dan Ekonomi. Yogyakarta: UPP-AMP YKPN.

Nejad, B.A. \& Abbaszadeh, M.M. S. 2010. Managers Empowerment in High School by Knowledge Management. Journal World Academy of Science, Engineering and Technology, Vol,67, hal. 609-613.

Nawaz, N, Gomes, M.2014. Review of Knowledge Management in Higher Education Institutions. European Journal of Business and Management. ISSN 2222-1905 (Paper) ISSN 2222-2839 (Online) Vol.6, No.7, hal. 71-79

Odoguwu, C, Chukwudi, F dan Chidi. 2012. Motivation and Employees' Performance in the Public and Private Sectors in Nigeri, International Journal of Business Administration Vol. 3, No. 1, hal. 3140

Peraturan Pemerintah Nomor 19 Tahun 2005 Tentang Standar Nasional. Pendidikan

Petrides, L.A. \& Nguyen, L. 2006. Knowledge Management Trends: Challenges and Opportunities for Educational Institutions. Metcalfe, Amy Scott (editor), Knowledge Management and Higher Education. A Critical Analysis. Published in the United States of America by Information Science Publishing (an imprint of Idea Group Inc.) 701 E. Chocolate Avenue Hershey PA 17033, hal. 2133

Petrides, L.A. \& Nodine, T.R. 2003, Knowledge Management in Education. Institute for The Study of Knowledge Management in Education. 1 Mirada Road. Half Moon Bay CA 94019, hal. 1-30

Qwaider, W. 2011. Integrated of Knowledge Management and E-Learning System. International. Journal of Hybrid Information Technology, Vol.4,No.4, hal. 218-221

Salo, N. 2011. Knowledge Management in Education in Indonesia: An Overview. Global Journal of Human Social Science. Volume 11 Issue 1 Version 1.0 February 2011. Type: Double Blind Peer Reviewed International Research Journal. Publisher: Global Journals Inc. (USA). ISSN:0975-587X, hal. 31-44

Santoso, B. 2007. Penilaian Portofolio Dalam Matematika, Jurnal Pendidikan Matematika, Vol.1, No. 2, hal. 31-38

Sopandi, O, Sa'ud, S. 2016. Implementasi Knowledge Management di Perguruan Tinggi. Jurnal Administrasi Pendidikan Vol.XXIII No.2, hal. 1-12

USAID. 2013. Indeks Pendidikan Indonesia Naik, Kemdikbud Fokuskan Capaian Program. Diakses tanggal 10 Oktober 2017. Tersedia di http://www.kemendikbud.go.id./2014/04/23/. 